\title{
Statistical Evaluation of Social and Economic Factors of Development of State Models (The Case of Developed and Developing Countries)
}

\author{
Larisa Demidova \\ Department of statistics \\ Moscow, Russia \\ demidova-ln@mail.ru \\ Georgy Popov \\ Independent researcher \\ Moscow, Russia \\ slavageo@bk.ru
}

Plekhanov Russian University of Economics

\author{
Nadezda Goreeva \\ Department of Economics and statistics \\ Kaluga Branch RSAU MAU n. a. K. A. Timiryazev \\ Kaluga, Russia \\ goreeva.filina@gmail.com \\ Olga Savchina \\ Department of Accounting, Audit and Statistics \\ Peoples' Friendship University of Russia (RUDN \\ University) \\ Moscow, Russia \\ savchina-ov@rudn.ru
}

\begin{abstract}
The paper presents the study of models for social and economic development of states, based on their indicators of sector efficiency and social development, incorporated in a factor model. The object of the study is a sample of developed and developing countries. The subject of the study is the selection of quantitative parameters of social and economic development models.

The paper describes the system of models for the states with different social and economic development levels and presents the main provisions for collection and processing of data. As the discussion unfolds, we select the analytical methods and use the correlation and regression analysis to identify the main factors the define social utility.

The actuality of this research lies in the fact that, at present, there is a redistribution of gross added value and GDP in the world towards countries - consumers. The backwardness of this social and economic structure is due to the situation in the international division of labor. The dualism of a social and economic system in these states is related to the priority that is given to market mechanisms over social policy in the context of globalization. We suggest that it is the social utility that should ensure the multi-sided development of human potential, which in turn contributes to the economic growth.

A special attention in building the models is given to estimation of the parameters for the countries that showed maximum divergence (residuals) of indicators, characterizing the social stratification and the development of human potential
\end{abstract}

Keywords: effectiveness of social institutions, factors of human capital (potential) development, the dualism of the world economic system, structure of gross value added, correlation and regression analysis, social usefulness of the state, factors determining the effectiveness of state institutions, quantitative analysis of the factors that shape the effectiveness of state institutions, factors of efficiency of world labor productivity, factors of public utility of the world economic system

\section{INTRODUCTION}

After the end of the Second World War and collapse of the colonial system there appeared a group of countries in the world map that were named as the third world counties.

At that time Russia and the United States were the major political rivals, with Russia heading the so-called socialist block countries, while the United States heading the capitalist countries. There was an unreconciled conflict between the rival systems for the future of developing countries in all the domains from industrial espionage and infamous "brain wash" to political sabotage and expansive military intrusions aimed at overthrowing the undesired regimes.

Until the end of the 80-s, each of the antagonistic sides tried to create its own zone of influence, attempting to maximize their power in the third world countries. This leads to the emergence of countries with socialist orientation, that fell into the zone of interest of the USSR.

However, in the very beginning of the 90 -s, after the USSR disintegration and the socialist camp collapse, the situation changed dramatically. The unipolar world, headed by the United States, evolved into a bio-polar one, with the second pole being divided between the European countries 
As the second step of the study, we identified the main and Japan. Other countries were considered to be satellites equally distant from the center and depending on the functions, which they performed in a newly formed system of coordinates. Russia found itself among second-tier countries with relatively low level of economic development, shrinking population, and lack of own development strategy. At the same time the country had a vast territory and, most importantly, contrary to China, India, and Brazil, military and nuclear potential that was comparable to that of the United States [1-3].

The transition to market economy meant in fact a complete rejection of the previous ideology of development that was based on the public property. This transition resulted in privatization of the public property in 1991 when the enormous Soviet empire disintegrated.

The cutoff of the existing economic structure and the sharp decline in revenues from exports of mineral resources due the structural changes in the world markets, did not allow Russia to change the model of economic development and occupy a deserved place in the international division of labor [4].

At the same time, the 90-s saw a social and economic structure starting to shape up in Russia and developing into a structure with underlying features that distinguish a transition economy from developed countries. Naturally, there arises a question: what are these features and what are their dynamics for the past two and a half decades of development of modern Russia? What factors influence the development of any given social and economic model of state?

The socio-economic development of States is determined by the effectiveness of the development of their institutions aimed at the maximum realization of human potential. Initially, economic growth should not lead to significant development of education, medicine and other sectors. The development of these industries only indirectly influences the expansion of human capabilities. The role of the state here is to create conditions for the development of all members of society, stimulating the potential abilities of each member of society, which in turn will contribute to the development of technology and the economy of the country [5].

\section{LITERATURE REVIEW AND RESEARCH METHODS}

Our research methodology encompasses the following three key components:

1. design of the system of indicators, which characterize the processes of social and economic development of models of state (both developed and developing);

2. high-level overview of the process of collecting and processing of data and selection of analysis methods; and,

\section{3. calculation and interpretation of research results.}

As the first step, we built a factor model based on the data from 42 countries: 27 EU countries (main developed countries); 5 BRICS countries (the semi-developed countries); 10 Asian and Latin American countries (where the model of social and economic development for the last decades permitted to take leading positions in their respective regions). basic factors that form social utility of an economic model, determining the basis for selection of an effective feature of economic structure.

\section{RESEARCH RESULTS}

Economies, that exist at the expense of exploitation of natural resources and as a result position the international division of labor for long-term inactivity, can be characterized by the common feature: underdevelopment of social and economic structure.

In the short run, attempts to improve the social and economic structure leads, as a rule, to the situation chasing the economic efficiency. However, the efficiency of state should be determined by the level of the public utility, rather than solely by the economic efficiency of national activity. The income, generated in effective industries and fields of national economy, is transferred to the state to support distributive relations amongst the recipients. As a result, the effective industries, do not receive back enough funds for their own development.

As a result, there arises a strong differentiation of incomes across the industry sectors and groups of population. This does not permit to use a human capital to the full extent. Evaluation of the factors, which lead to such a situation, is one of the vital tasks, as it would permit to successfully solve the problem of creating favorable conditions for development of the society and the economy.

The most convenient form for factorial analysis is building correlation models, which permit to quantitatively evaluate the influence of each taken indicator on a social efficiency of life of every member of a society [6].

The countries with high living standards (European Union countries), average living standards (BRICS countries, i.e. developing countries such as China, Indonesia, Malaysia), and low living standards (Peru, Columbia, Chile and others) were taken into a regression model.

The analysis of 2017 correlation of the Gini coefficient, which shows the degree of social differentiation, with 4 indicators, which characterize the economy development efficiency (index of consumer confidence, index of a human potential development, inflation index, and a share of hightech industries in GDP of countries) prove the presence of a rather strong relationship.

The three-factor model included only the index of a human potential development, inflation index, and the share of hightech industries in GDP of countries. The results of modelling are presented in Table I. 
TABLE I. RESULTS OF A CORRELATIVE-REGRESSIVE ANALYSIS OF THE WHOLE SET OF 42 WORLD COUNTRIES

\begin{tabular}{|c|c|c|c|c|c|c|c|c|}
\hline \multirow[t]{2}{*}{ Indices } & \multicolumn{4}{|c|}{$\begin{array}{l}\text { Four-factor model } \\
\text { Y }(x)=0.12-0.049 X_{1}-52.73 X_{2}+ \\
0.80 X_{3}+0.33 X_{4}\end{array}$} & \multicolumn{4}{|c|}{\begin{tabular}{|c|} 
Three-factor model \\
$\mathrm{Y}(\mathrm{x})=0.99-54.29 \mathrm{X}_{1}+$ \\
$0.77 \mathrm{X}_{2}+\mathbf{0 . 3 2} \mathrm{X}_{3}$ \\
\end{tabular}} \\
\hline & $\begin{array}{c}\text { Index of } \\
\text { consume } \\
\mathbf{r} \\
\text { confiden } \\
\text { ce }\end{array}$ & $\begin{array}{c}\text { HPD } \\
\text { I }\end{array}$ & $\begin{array}{c}\text { Index } \\
\text { of } \\
\text { inflati } \\
\text { on }\end{array}$ & \begin{tabular}{|c}
$\begin{array}{c}\text { Share } \\
\text { of high- } \\
\text { tech }\end{array}$ \\
industri \\
es in \\
GDP
\end{tabular} & $\begin{array}{c}\text { HPD } \\
\mathbf{I} \\
\left(\mathbf{X}_{1}\right)\end{array}$ & \multicolumn{2}{|c|}{$\begin{array}{c}\text { Index } \\
\text { of } \\
\text { inflatio } \\
n\left(X_{2}\right)\end{array}$} & \begin{tabular}{|c|}
$\begin{array}{c}\text { Share } \\
\text { of high- } \\
\text { tech }\end{array}$ \\
industri \\
es in \\
GDP \\
$\left(X_{3}\right)$ \\
\end{tabular} \\
\hline $\begin{array}{l}\text { Regression } \\
\text { coefficient }\end{array}$ & -0.04 & $\begin{array}{c}- \\
52.73\end{array}$ & 0.80 & 0.33 & $\begin{array}{c}- \\
54.2 \\
9\end{array}$ & 0.7 & & 0.32 \\
\hline $\begin{array}{l}\text { Coefficient } \\
\mathrm{s} \text { of pair } \\
\text { correlation }\end{array}$ & -0.05 & $\begin{array}{c}- \\
0.65\end{array}$ & 0.59 & 0.56 & -0.65 & 0.5 & & 0.56 \\
\hline \multicolumn{9}{|c|}{$\begin{array}{l}\text { Residuals of predicted values and minimum of discrepancies per a resultant } \\
\text { indicator }\end{array}$} \\
\hline & \multicolumn{4}{|c|}{ Four-factor model } & \multicolumn{4}{|c|}{ Three-factor model } \\
\hline $\begin{array}{l}\text { Residuals } \\
\text { of } \\
\text { predicted } \\
\text { values of } \\
\text { Gini index }\end{array}$ & \multicolumn{2}{|c|}{ 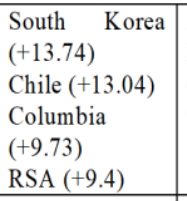 } & \multicolumn{2}{|c|}{$\begin{array}{l}\text { Indonesia (-11.96) } \\
\text { Russia (-8.02) } \\
\text { Czech Republic (- } \\
9.02)\end{array}$} & \multicolumn{2}{|c|}{$\begin{array}{l}\text { Chile }(+) \\
\text { RSA }(+) \\
\text { Columbia } \\
(+)\end{array}$} & \multicolumn{2}{|c|}{$\begin{array}{l}\text { Indonesia (- } \\
\text { ) } \\
\text { Czech } \\
\text { Republic (-) } \\
\text { Rumania (-) }\end{array}$} \\
\hline $\begin{array}{l}\text { Minimum } \\
\text { discrepanc } \\
\text { ies of } \\
\text { factual and } \\
\text { predicted } \\
\text { values of a } \\
\text { resultant } \\
\text { indicator }\end{array}$ & \multicolumn{2}{|c|}{ China $(+0.05)$} & \multicolumn{2}{|c|}{$\begin{array}{l}\text { France }(-0.11) \\
\text { Bulgaria }(-0.02)\end{array}$} & \multicolumn{2}{|c|}{$\begin{array}{l}\text { Luxembur } \\
\mathrm{g}(+) \\
\text { Lithuania } \\
(+)\end{array}$} & \multicolumn{2}{|c|}{$\begin{array}{l}\text { Peru (-) } \\
\text { Portugal (-) }\end{array}$} \\
\hline
\end{tabular}

* Calculated by authors on the basis of Eurostat data.

Overall, the factors included in both models show a rather considerable influence of a human potential development index (HDPI), the level of inflation expectations, and the degree of technological development of industries (multiple correlation coefficients in models were respectively equal to $\mathrm{R}=0.72$ and 0.74 ). One should also note the inverse negative relationship between HDPI and Gini coefficient, meaning that HDPI increase leads to the reduction of social differentiation and inequality of the population. Moreover, the four-factor model based solely on the set of EU countries did not show a substantial relation between factors $(\mathrm{R}=0.33)$, i.e. the main contribution into evaluation of interrelations are not made by developed countries with insignificant variation, but by developing countries with dispersion residuals of variables being considerably varied.

The results of a four-factor model showed a lack of a considerable influence of an entrepreneurial confidence index, which is related to the influence of a temporary lag in the given index.

Consumption purchasing expectations of entrepreneurs are included in this composite index. Therefore, flexibility of retail market supply and inclusion of a dynamic component into this indicator slightly influence the degree of social differentiation of population incomes.

The model suggests that in a modern globalized world the superiority of market mechanisms over social policy is unable to insure sustainable economic growth and welfare of a society, in both poor and developing countries [7].

The growth of the economy on its own does not lead to a considerable improvement of education, healthcare quality, or reduction of poverty and stratification of a society. It does not improve social utility of a society in majority of countries, even in the developed world [8-9]. The degree of economic development only partially and to a limited extent assists in the realization of human potential and broadens a human's opportunities to realize his/her skills, which in turn should become the engine for progress. In this case, the role of a state is in rendering such opportunities equally to every member of society, stimulating a human's potential abilities, insuring equal distribution of results and driving growth of the economy.

Our comparative analysis of residuals (maximum discrepancies of factual and predicted values) in a four-factor and three-factor models in every country showed that for a three-factor model in such countries as Chile, Columbia, and South Africa, an attained value of Gini coefficient is above the level that is theoretically predetermined by a regression equation. This means that the index of social stratification has a considerably bigger value than it should be in these countries. Such a situation can be stipulated by current social and economic model, which was shaped in the given states, as well as their insignificant place in international division of labor and contribution in the world GDP. The resulting residuals also showed that factual values did not reach theoretically distributed ones in Indonesia and Czech Republic. This means that factual values of the degree of social differentiation in these countries are below modeled values under specified values of the human potential development index (HPDI), the level of the inflation expectations, and the degree of sector technological effectiveness.

There are also maximum discrepancies in countries such as South Korea (+13.74) and Russia (-8.02) in the four-factor model. And if for South Korea the resulting value of Gini coefficient is stipulated by a high real level of social utility for its economy, the institutional transformations in Russia have a negative result, which does not lead to the improvement of both economic situation and efficiency of a human's selfrealization in a society.

\section{CONCLUSION}

Models of developed and developing countries have shown that in modern conditions the state's emphasis on superiority of market mechanisms over social policy can lead to stable economic growth but not to increased welfare of a society.

The economic development in the majority of countries does not actually lead to effectiveness of social institutions or reduction of income inequality. And this holds true even for developed countries. In this case the basic strategy of state programs should be aimed at development of human potential of every member of the society.

Russia as a country-consumer, rather than a manufacturer of modern technologies, cannot develop its economy without 
[4] V.P. Kolesov, M.N. Osmova, World Economy. Economy of countries and regions. Textbook, 2015, p. 519.

creating an effective social infrastructure aimed at the development of human capital through the formation of intellectual and innovative environment. Institutional transformations should involve an innovative value chain that would include fundamental research, applied R\&D, and commercial technologies. Only in this case the Russian domestic economy can compete with China, India, and other countries [10-11]. Institutional developments in the form of the fund of national welfare and state funds for development should become the key tools to solve the strategic problems of the economy formation. It is also required to form such institutions of development as techno parks, business incubators, and technology transfer centers, all in in the conditions of insufficient financing [12-15].

The main dilemma today encompasses the role of the state in the Russian Federation as a subject of economic activity and the necessity of cardinal changes in the legal and judicial system [16- 17]. If these changes do not take place, the differentiation between poor and rich countries will deepen even further [18]. Furthermore, the obsolete structure of the economy creates a dependent development path. The current challenges are due to the fact that from the one side, there is a requirement to develop market institutions [19], and from the other side, there arises a requirement to increase social purposes of these institutions [20]. Today such dualism remains one of the most important issues of many states.

\section{ACKNOWLEDGMENTS}

The publication has been prepared with the support of the "RUDN University Program 5-100" (recipient - Olga Savchina).

\section{REFERENCES}

[1] O.O. Okediji, "Institutions and economic development: theory, policy and history," Journal of Institutional Economics, vol. 7(4), 2011, pp. 473-498.

[2] L. Ferrini, The Importance of Institutions to Economic Development, [Electronic source]. URL:. http://www.e-ir.info/2012/09/19/theimportance-of-institutions-to-economic-development/.

[3] N.A. Petrov, Impact of changes in production factors correlation on cyclical development in global economy [Text]: auto-abstract thesis Candidate for economic sciences, 2015, p. 22.
[5] R.I. Kapelyushnikov, Productivity and labor remuneration: a little bit of simple arithmetics, 2014, p. 40.

[6] N.M. Goreyeva, L.N. Demidova, S.I. Chernyaev, " Analysis of the factors forming relationship of gross regional product growth and living standards in the Kaluga region," Modern problems of science and education, vol. 2, 2013, p. 339.

[7] Forecast of scientific and technological development of the Russian Federation for the long term. [Electronic source]. URL: http://www.sciinnov.ru/files/materials/6817/08/12/18-prog.ntr.pdf

[8] A.A. Marinov, Developing regional innovation subsystem on the basis of the government and business interests coordination, 2014.

[9] O.A. Sdvizhkov, Non-parametric statistics in MS EXCEL and VBA, 2014, p. 172.

[10] N.M. Goreeva, L.N. Demidova, S.I. Chernyaev, "The world crisis influence on Russia economic stability," Modern problems of science and education, vol. 1, 2013, p. 289.

[11] S.I. Chernyaev, N.M. Goreyeva, L.N. Demidova, I.Y. Ogloblin, "The fractal nature of the Russian financial system during crisis," European science review, vol. 5-6, 2014. pp. 235-239.

[12] Basic concepts of institutional economy [Electronic source].Central $\begin{array}{lll}\text { Science } \quad \text { Library. } & \text { [Electronic sourse]. }\end{array}$ URL: http://www.0ck.ru/ekonomika_i_ekonomicheskaya_teoriya/osnov nye_ponyatiya_institucionalnoj.html.

[13] D.V. Chaykovsky, Theory and methodology of the formation and application of value added under IFRS on a micro and macro level, The thesis abstract, 2011.

[14] A.A. Moskovskaya et al., Social entrepreneurship in Russia and in the world: practice and research, 2011. [Electronic sourse]. URL:https://www.hse.ru/data/2011/11/01/1269337965/04.pdf.

[15] G. Khelmke, C. Levitski, Non-formal institutions and a comparative policy: basic research fields, [Electronic source]. URL:http://www.intelros.ru>pdf/prognosis2_07/Helmke.pdf.

[16] R.M. Shakhnovich, Inflation and anti-inflationary policy in conditions of radical reforms, 2014, [Electronic sourse]. URL:http://av.disus.ru/dissertatciya/1042961-1-inflyaciyaantiinflyacionnaya-politika-usloviyah-radikalnih-reform.php.

[17] A.A. Porokhovsky, The economic system of modern Russia: ways and objectives of development: Monograph, 2015, p. 896.

[18] P.D. Shimko, World Economy and International Economic Relations, A textbook and a manual for undergraduate and graduate students. Textbook, 2017, p. 392.

[19] N. Birdsall, The (Indispensable) Middle Class in Developing Countries; or The Rich and the Rest, Not the Poor and the Rest, Working Paper Center for Global Development, 2010, p. 207.

[20] N.M. Goreyeva, L.N. Demidova, "Institutional transformations in Russia and their development in statistics," Kaluga economic herald, vol. 1, 2016, pp.66-72. 